\title{
Investigating Business Drives : Intellectual Capital To Marketing Mix
}

\author{
Roymon Panjaitan ${ }^{1 *}$, Muhammad Iqbal Fassa ${ }^{2}$, Deddy Sulaimawan ${ }^{3}$, Dian Indriyani ${ }^{4}$ \\ ${ }^{1}$ Faculty of Computer and Business, Universitas Sains dan Teknologi Komputer \\ Semarang, Indonesia. \\ ${ }^{2}$ Universitas Islam Negeri Raden Intan Lampung, Indonesia \\ ${ }^{3}$ AMIK DCC, Lampung, Indonesia \\ ${ }^{3}$ National Institute of Public Administration, Indonesia \\ * Corresponding Author: \\ Email: roymon_panjaitan@yahoo.com
}

\begin{abstract}
.
This paper examines the relation of intellectual capital relations in consumer behaviour with social media to the effectiveness of the marketing mix. Sampling as much as 98 responding with the type of sampling quota, data collection techniques with the questionnaire and interviews. The test coefficient of Path in PLS-SEM is used in this study to contribute data from the analysis of the path of consumer behaviour by using social media. Results found that variables of consumer behaviour and social media advertising have a significant effect on the marketing mix, whereas intellectual capital as a liaison variable is not significantly influenced by consumer behaviour and does not significantly affect the marketing mix. Total direct and indirect influence of consumer behaviour variables $54.4 \%$ and social media variables at $40.8 \%$ to the marketing mix
\end{abstract}

Keywords: Consumer Behavior, Social Media, Marketing Mix, Intellectual Capital, PLS

\section{INTRODUCTION}

Intellectual capital is an intangible property that is worth optimizing the company's business $[1,2]$. In line with the studies of $[3,4]$, they explain that intellectual capital contributes directly to marketing performance. But according to [5]-[7], marketing performance should be supported by the process of technological innovation and marketing through social media. The higher the processability, management, and innovating new products, it will increase financial and marketing performance [8], [9]. [10] Arguing disruption occurs because information technology is radically diffused the behavior of human life [11], [12]. So, it is significantly necessary for the improvement of the company's productivity in designing marketing strategies.

The fact that occurs, in the industry there is still a gap in human behaviour that has not been able to utilize intellectual capital to design new business strategy [13]. Consumer behaviour in the era of globalization will change the mindset to acquire a product that is influenced by the factors of quality, price and technology [14]-[17]. The technological adaptation process is one of the individual productivity efforts for organizational or corporate performance [18]-[21]. The transformation from physical http://ijstm.inarah.co.id 
capital investment to the intellectual capital innovation sector will minimize production and service costs [4], [22]-[24]. Broad marketing performance is still a problem in implementing intellectual capital strategy, in addition to physical capital.

On the other, intellectual capital is often discussed and has positive implications in financial performance [25]-[27]. To further increase productivity [28] develops 3 market-based models that contribute to the increased value of the company's marketing and financial performance. Similarly, it is expressed by [29]-[32] Human skills factor, innovation ability can measure consumer loyalty to a brand for pricing, where price as one of the marketing mix elements.

The discussion so far encountered a holistic model research gap that combines the flow of literature, methods, tools and variables intervening the understanding of contingency and interrelationship complex consumer behaviour and social media towards the correctional mix. The research aims to fill the previous research vacancy linking the intellectual capital from the perspective of consumer behaviour (CB) and social media Advertising (SMA) which affects the performance of the marketing mix. Besides, we include the direct and indirect effects of $\mathrm{CB}$ and SMA against the marketing mix, as well as the IC variables that intervene between variables. The purpose of our problem is to investigate how IC's role strategy contributes higher in the effectiveness of the company's marketing mix performance strategy.

This study contributes to the literature in the following ways. First, the paper combines static and dynamic perspectives on intangible in an integrated framework and by providing theoretical and empirical support for the relationship between $\mathrm{CB}$, SMA and market performance. Secondly, at the methodological level, we combine symmetrical and asymmetric statistical tools to better understand contingencies and interactions between CB, SMA and market performance. Thirdly, our research shows that the ability of the supplier's blend strategy is optimal when combined with the specific source of IC resources to excel at the market performance. Fourth, we can give input to the company's manager how to empower IC resources through consumer behaviour and social media development as a superior initiative in the market. Therefore, the paper potentially offers theoretical and empirical foundations for the future.

\section{HYPHOTESIS DEVELOPMENT AND METHODS Hyphothesis Development Consumer behavior}

Consumption is the goods and services used to satisfy human desires [33-34]. [35] argues that individuals may use consumption as a way to manage and regulate their emotions. The consumption of goods and services, especially luxury goods such as four-wheeled vehicles, has become an important lifestyle choice for consumers to demonstrate wealth, acquire social status, and seek uniqueness [36]. 
Consumer behavior is one of the marketing theories in which individual aspirations and motivations play an important role [37]. Consumerism has become a culture, practised by virtually every layer of society for a variety of reasons, where the role of media is very important.

The consumer behavior theory has two key features: (1) Consumers choose the best alternative asset among the actions that are open to him, and (2) the main determinant of consumer spending, aside from taste, is income (absolute or relative) or, according to newer formulations, normal or permanent household income [38-39]

\section{Social Media Advertising}

Researchers acknowledge that the range of Internet-supported devices that buyers use to search for product information or to purchase products online has expanded [40-41]. Companies are increasingly interested in digging marketing insights from social media data [42 - 43]. [44 - 45] states that social media is a communication that continues to grow exponentially, growing faster and changing more than any other Internet activity. In recent years, social media has become an important advertising platform for brands that want to reach online consumers [46], [47]. Social Media is widely used by the crowd to communicate, look for consumer information [48].

\section{Intellectual Capital}

Intellectual capital includes a variety of intangible resources including knowledge, competence, branding, databases, routine resources and human beings that are the main source of organizational value creation as well as the main drivers of competitive advantage [49]-[51]

Intellectual Capital refers to a cumulative amount of organizational resources consisting of knowledge, skills, competencies, experiences and intellectual property that collectively add value to the organization [52]-[54].

Intelectual Capital facilitates the determination of a competitive market position of a company especially when its physical assets are no longer able to achieve sustainable excellence. This is because Intelectual Capital's ability is unique $\&$ cannot be substituted and varies from company to company, so investment in Intelectual Capital depends on the type of company [55], [56].

\section{Marketing Mix}

Marketing systems and emphases, intensifying the role and practice of marketing, methodical advertising, social and decent marketing, globalization and global marketing contest, marketing in a new economy, creating and working miscellaneous products, strategic marketing, and enlarging the concept and accomplishment of marketing [57]-[61]. The act of marketing mix is the power and size of marketing components such as products, prices, places and publicities compulsory to achieve marketing objectives [61]-[64] 
Rendering to [65]-[67] features of human capital (attitudes, training and skills of staff), operational investment (culture, technology and internal organization of the company) and social capital (customer relations and suppliers, cooperation and corporate image).

\section{Consumer Behavior and Marketing Mix}

Consumers use metrics such as awareness, consideration and preference as indicators define to advocate for brands and easily connect to marketing activities [68], [69] [70], [71]. From Empirical Evidence [72]-[74]. There are known influences of the marketing mix element on food purchase behaviors in five supermarkets validating theoretical models, demonstrating a positive relationship between the marketing mix variables and the significant relationship between designing effective marketing and purchasing behaviour within the industry. Consumer behaviour in shopping has a cognitive and affective experience, the affective experience has a higher impact on customer satisfaction and a positive word of mouth into a successful shopping context, while in the context of the failing shopping experience cognitive has a higher impact on the negative discontent of the mouth [75]-[78]. From the explanation above, the research hypothesis is as follows:

H1: Consumer behaviour positively affects the marketing mix

\section{Social Media Advertising and Marketing Mix}

Social Media is a hybrid element of the promotion mix because in the traditional sense it allows the company to talk to their customers, while in a nontraditional sense it allows customers to speak directly to each other [79]-[81]. In line with research [82], [83] social media has become a very important gradient in the marketing mix and a key node for all businesses, especially in industries where trends are constantly changing helping consumers in purchasing decision making [82], [84][86]. However, according to [87], [88] demonstrates this impact the evolution of the revolution and the adoption of technology that alone does not guarantee a competitive edge so that companies must continue digging by developing superior products. This research suggests the following hypothesis:

$\mathrm{H} 2$ : Social media ads have a positive effect on the marketing mix

\section{Intellectual Capital and Marketing Mix}

From the research results [89]-[92] discuss much more of the link between intellectual capital and financial performance, on the other hand, some other studies [93]-[98] discuss intellectual capital can help to dissemination of marketing performance in business that will increase the company's finances. Intellectuals become the basis of the election price, place, promotion and product what is true can fulfill his wishes and needs [99]-[101]. The purchasing decision process is expected to lead to the purchase response which is the buyer's choice, choice of brand, reseller 
choice, time of purchase, and number of purchases [102]. From the explanation above, it can be suspected as follows:

H3: Intellectual capital has a positive effect on the marketing mix

\section{Social Media Ads and Intellectual Capital}

Social Media is a stimulus to think and gain perception of something things in the cognitive areas (intellectuals). All information conveyed by social media is captured in the senses and processed into the perception of such products/services and is complex described in the area of neuromarketing. So it is important for the company to know the specific segments of the market that are targeted and build the right branding and social media ads to be the perspective expected by the manufacturer to the products/services offered [102]
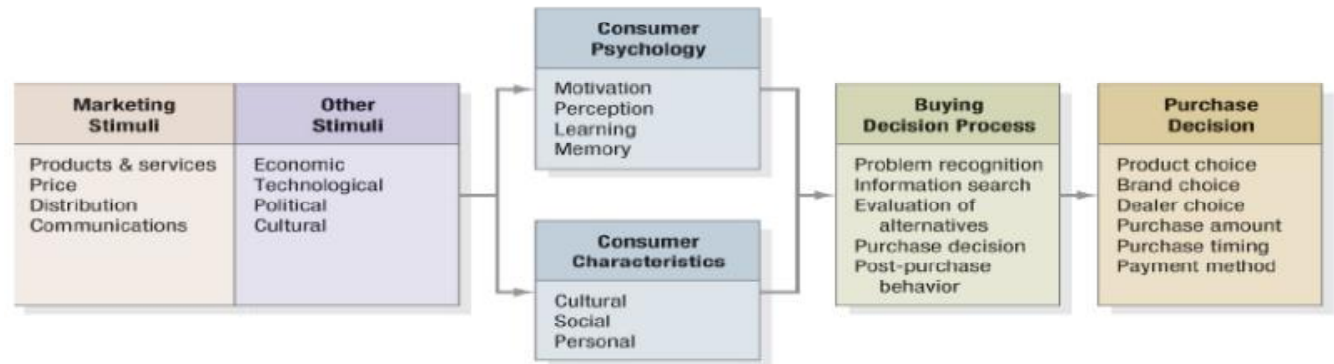

Source : Manufacturer to the products/services offered [102]

From the information above, it can be assumed as follows:

H4: Social media advertising has positive implications for intellectual capital

\section{Consumer Behavior and Intellectual Capital}

In literacy, consumer behavior not only discusses what is purchased, but also why they want to buy, when, where, how manufacturers evaluate purchases and how they eventually use post-purchase products [103]-[105]. Adoption of technology becomes a phenomenon that transforms the consumer domain into a major alternative to meet the needs [106]-[108] The same thing from the perspective [109]-[113] to reach towards a successful marketing, environmental and consumer behavior as a daristic indicator of marketing strategies. Therefore, consumer behavior will be contaminated from any social environment from what is seen or heard in interacting. From the description above then the alleged temporary as follows:

$\mathrm{H} 5$ : Consumer behaviour with positive implications for intellectual capital

\section{Methods}

Based on data and observation conducted by researchers, the type of descriptive qualitative research with causal approach. A total of 98 respondents became samples by the purposive testing method and the source of data objects that would be processed from the distribution of polls, documentation and discussion to $80 \%$ of young millennials and the remainder to the wider community across generations. The endogenous variables discussed in the processing of data come from consumer http://ijstm.inarah.co.id 
behaviour habits as well as social media ads, while the marketing mix as an exogenous variable is also linked to intellectual capital. Primary Data is processed in a descriptive statistical analysis using the analysis of the line PLS with evaluation of the outer model before and after the implementation of the test, the alleged testing while in this research conducted statistical data calculation of Structural Equation Modelling (SEM) Analysis as a quantitative analysis.

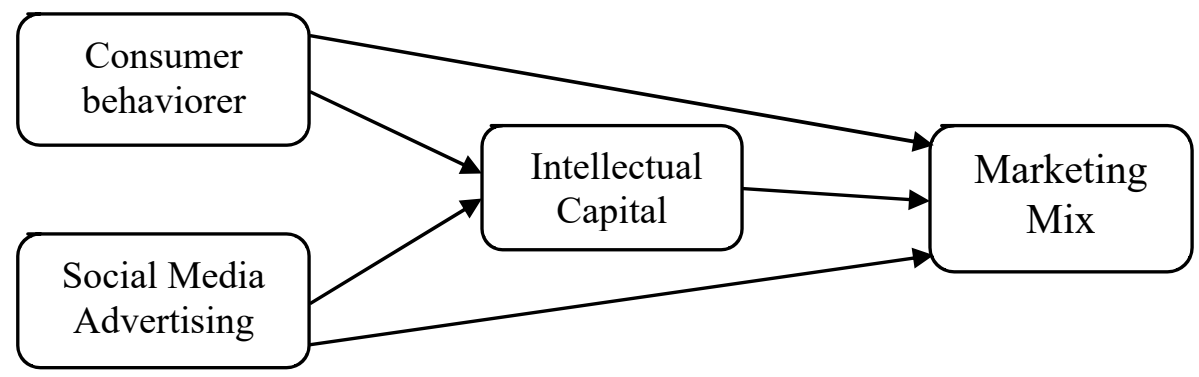

\section{Variables Measurement}

Fig 1. Conceptual Framework

A statement that disseminated researchers to the community around the campus as many as 19 items statement and arranged into 4 categories: 5 (five) statements are indicated for measuring consumer behaviour (X1), 4 (four) statements used to measure social media advertising (X2), 5 (five) statements used to measure intellectual capital (Z) and 5 (five) statements are used to measure the marketing Mix (Y). Data that is processed using the Likert scale is used to establish attitudes, opinions and representatives of individuals or in organizational groups about social phenomena. Social event events are the findings for researchers to further examine the reference in determining variables. Likert scale score calculation i.e. SS answer worth $5, \mathrm{~S}$ worth 4 , $\mathrm{N}$ rated 3, TS worth 2 and STS rated score 1. Results of the answers that researchers acquired data from respondents were consumer behaviour (X1), Social Media ads (X2), Intellectual Capital (Z) and Marketing Mix (Y).

\section{RESULT AND DISCUSSION \\ Outer Model Evaluation}

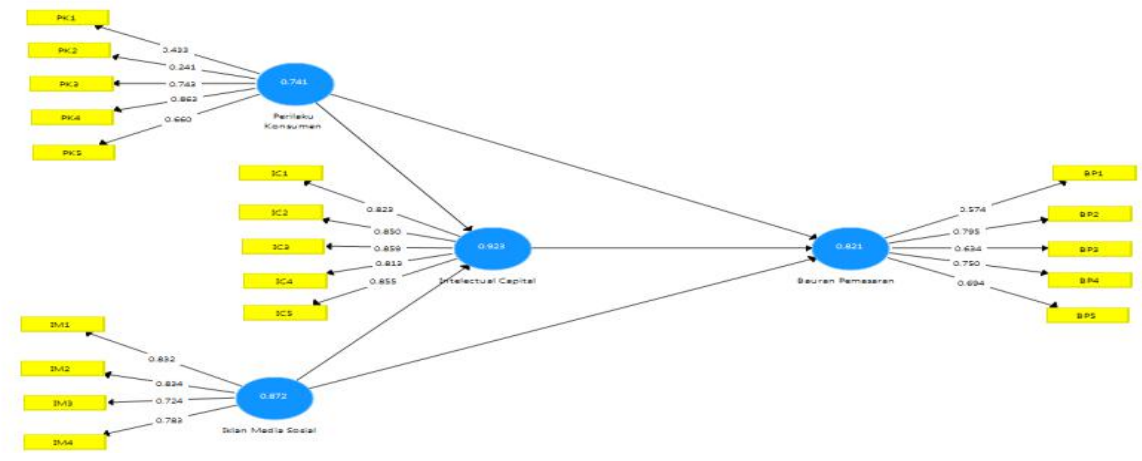

http://ijstm.inarah.co.id 
Fig 2.

Figure Outer Model Before Testing

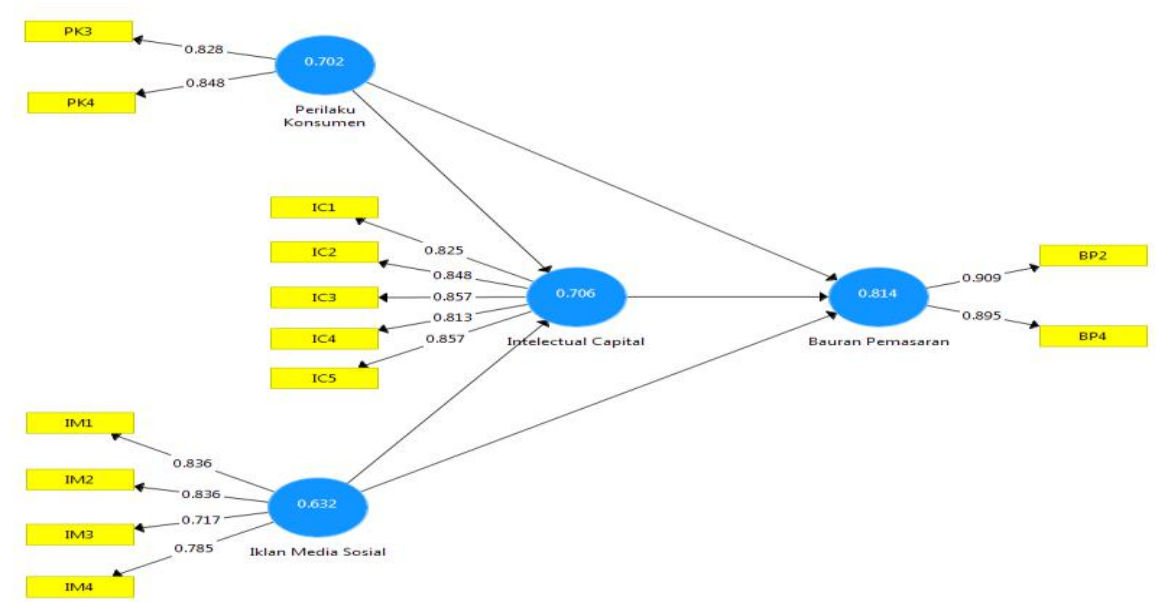

Fig 3.

Figure Outer Model After Completion of Testing

\section{Convergent validity}

The result of data validity from convergent validity to determine the level of reliability, can be seen from the standardized loading factor that displays the number of variables interference linearity with its construction. The following are the different filling that can be calculated from the following data testing:

Table 1. Outer filling

\begin{tabular}{|c|c|c|}
\hline Variable & Size & Outer filling \\
\hline \multirow{5}{*}{$\begin{array}{l}\text { Consumer } \\
\text { behavior } \\
\text { (X1) }\end{array}$} & PK1 & 0.433 \\
\hline & PK2 & 0.241 \\
\hline & PK3 & 0743 \\
\hline & PK4 & 0863 \\
\hline & PK5 & 0.660 \\
\hline \multirow{4}{*}{$\begin{array}{l}\text { Social Media } \\
\text { Advertising } \\
\text { (X2) }\end{array}$} & IM1 & 0832 \\
\hline & IM2 & 0834 \\
\hline & IM3 & 0.724 \\
\hline & IM4 & 0.783 \\
\hline \multirow{2}{*}{$\begin{array}{l}\text { Intellectual } \\
\text { capital } \\
\text { (Z) }\end{array}$} & IC1 & 0823 \\
\hline & IC2 & 0850 \\
\hline
\end{tabular}

http://ijstm.inarah.co.id 


\begin{tabular}{|c|c|c|}
\hline & IC3 & 0.859 \\
\hline & IC4 & 0813 \\
\hline & IC5 & 0.855 \\
\hline & BP1 & 0.574 \\
\hline Marketing & BP2 & 0795 \\
\hline Mix & BP3 & 0.634 \\
\hline & BP4 & 0750 \\
\hline & BP5 & 0.694 \\
\hline
\end{tabular}

Source: SmartPLS.3 output, main data dlet's go 2020

Based on a processed table, there is a lot of research variable size that has an outer loading value $>0.7$. Other Data found there are some indicators that are outer loading under 0.7 , so the indicator is not worth the removal.

2. Linear Validity

Linear validity is a comparison of discriminant validity and square roots of an average extracted. When the construction value is greater than the correlation value with the other construct in a method, the value of linear validity is good worth $>0.5$

Table 2. Validity Test

\begin{tabular}{|c|c|}
\hline Variable & AVE \\
\hline Consumer Behavior (X1) & 0702 \\
\hline Social Media Ads (X2) & 0.632 \\
\hline Intellectual capital(Z) & 0706 \\
\hline Marketing Mix (Y) & 0814 \\
\hline
\end{tabular}

Source: SmartPLS.3 output, primary data processed 2020

The data described above is obtained from the numbers of consumer behavior variables, social media advertising, intellectual capital, and marketing mix $>0.5$. Then the discriminant validity results are excellent.

\section{Composite Reliability}

Composite reliability is a method that measures the level of reliability of a variable. Valid data Composite Reliability $>0.7$ signifies reliable data reliability. A block of indicators that measure a construct element can be identified using two ways that are inside dependability and Cronbach's alpha.

Table 3. Reliability Tests

\begin{tabular}{|c|c|}
\hline Variable & Composite Reliability \\
\hline Consumer Behavior (X1) & 0825 \\
\hline Social Media Ads (X2) & 0873 \\
\hline Intellectual capital(Z) & 0.923 \\
\hline Marketing Mix (Y) & 0887 \\
\hline
\end{tabular}

Source: SmartPLS.3 output, primary data processed 2020 
The acquisition of the figure above is known that the value of Composite Reliability all research variables $>0.7$. Successfully processed results have fulfilled the reliability standards of the above test.

\section{A. Inner Model Evaluation.}

\section{Path coefficient test}

Using the processing coefficient path can be known linkage of selfvariable with bully variables. The constant purpose (R-Square) is known to trace the amount between endogenous variables. Chin raised a R2 result worth 0.67 upwards for an endogenous latent variable in a structural model, can be concluded there was a variable influence of the bully that affects variables that are affected by good assumptions. When worth $0.33-0.67$ is categorized, and if its value is $0.19-0.33$ it is weak.

Based on the inner model scheme that has been shown in Figure 2, obtained formula:

Table 4. Hypothesis Testing

\begin{tabular}{|c|c|c|c|c|}
\hline Conjecture & Variable implications & $\begin{array}{c}\boldsymbol{t} \text { - } \\
\text { statistic }\end{array}$ & $\begin{array}{c}\boldsymbol{p} \text { - } \\
\text { value }\end{array}$ & Conclusion \\
\hline $\mathrm{H} 1$ & $\begin{array}{c}\text { Consumer } \\
\text { behavior } \rightarrow \text { Marketing Mix }\end{array}$ & 6,265 & 0,000 & Rejected \\
\hline $\mathrm{H} 2$ & $\begin{array}{c}\text { Social Media Advertising } \rightarrow \\
\text { Marketing Mix }\end{array}$ & 2,507 & 0.013 & Rejected \\
\hline $\mathrm{H} 3$ & $\begin{array}{c}\text { Consumer behavior } \rightarrow \\
\text { Intellectual capital }\end{array}$ & 0.157 & 0875 & Received \\
\hline $\mathrm{H} 4$ & $\begin{array}{c}\text { Social Media Advertising } \rightarrow \\
\text { Intellectual capital }\end{array}$ & 9,058 & 0,000 & Rejected \\
\hline $\mathrm{H} 5$ & $\begin{array}{c}\text { Intellectual capital } \rightarrow \\
\text { Marketing Mix }\end{array}$ & 0.904 & 0.367 & Rejected \\
\hline
\end{tabular}

Source: SmartPLS.3 output, data processed 2020

According to the table, it is known that the largest value of positive path coefficient is shown in the influence of social media ads to intellectual Capital obtained from the $\mathrm{t}$ - statistic table of 9,058 and $\mathrm{P}$-value value of 0.000 , and the second biggest influence is on the influence of consumer behaviour on the marketing mix t-Statistic of 6,265 and P-value value of 0.000 , while the remainder of the influence of social media ads on the marketing mix amounted to t-value of 2,507 and a P-value value of 0.013 , the intellectual influence on the marketing mix gained a figure of 0904 and a probability value of 0367 as well as the influence of consumer behaviour on intellectual capital with a T-statistic value of 0157 and a probability value of 0875 . From the description above, there is a positive path coefficient value. The number obtained means that the increase in the coefficient of the path value increases and the variable effect is free to impaired variables. 
From the number that has been done, it can be deduced the value of R-Square as follows:

Table 5. Path Coefficient Test

\begin{tabular}{|c|c|}
\hline Variable & R-Square Value \\
\hline Intellectual capital $(\mathrm{Z})$ & 0.369 \\
\hline Marketing Mix $(\mathrm{Y})$ & 0.300 \\
\hline
\end{tabular}

Source: SmartPLS.3 output, primary data processed 2020

Based on the data above, the value of R-Square variable intellectual capital (Z) amounted to 0369 and the marketing Mix (Y) of 0300. This figure can be explained the increase in intellectual Capital $(\mathrm{Z})$ of consumer behaviour and social media advertising of $36.9 \%$ and the magnitude of percentage increase of the marketing mix (Y) by $30 \%$.

\section{Hypothesis testing}

From the concept of research thinking framework written in this test, research obtained the alleged temporary that is Ho and Ha. The Ho symbol is assumed to have no influence, so Ha assumes there is an impactful allegation.

Knowing the accuracy of the allegations, a statistical test is needed with the calculation of SEM Analysis in the method of quantity analysis. According to Ghozali (2005:84) "The T-Statistic test basically shows how far the influence of one free variable is individually in a bound explaining".

From the alleged test the temporary known Ho was rejected if Probabilita $>0.05$. This results in the relationship between the following indicators.

1) Consumer Behavior to the Marketing Mix

Ho1: Consumer behavior impacts the marketing mix.

Ha1: Consumer behavior affects the marketing mix.

2) Social Media Ads on Marketing Mix

Ho1: Social media advertising does not affect the mix marketing.

Ha1: Social media advertisement impact on the marketing mix.

3) Effect of Consumer Behavior on Intellectual Capital

Ho1: Consumer behavior impact of intellectual capital

Ha1: Consumer behavior affects intellectual capital.

4) The Effect of Social Media Ads on Intellectual Capital

Ho1: Social media advertising does not affect intellectual capital.

Ha1: Social media advertising affects intellectual capital.

5) Effect of Intellectual Capital on Marketing Mix

Ho1: Intellectual capital does not affect the marketing mix.

Ha1: Intellectual capital influences the marketing mix.

\section{B. DISCUSSION}

Some research has already been conducted using SEM analysis to test the cause method due to variable indicators, which is known to find the process of inaccuracies between variables. No normalcy is indicated that there is no normal distribution of data. 
However, if the data is already in the standard univariate not necessarily the data is normal distribution multivariate, therefore based on test normality, there are irregularities. The steps required with SEM analysis are model specifications, model identification, model estimation, match test, and Specification. From data output PLS 3, the structural model is said precisely done to know the relationship is not needed respecification method by fixing the matching model

The intellectual capital $(\mathrm{Z})$ variable obtained an R2 value of 0369 , this figure demonstrates consumer behaviour and social media advertising can account for $36.9 \%$ of the intellectual capital variant, and $63.1 \%$ gained by other factors. The marketing mix variable (Y) obtained an R2 value of 0300 , this figure demonstrates consumer behaviour and social media advertising by $30 \%$ variant of the marketing mix, while the remaining $70 \%$ is obtained by other factors.

From the known research results:

1. H1 Hypothesis: From the results of a provisional estimate of $95 \%$, the probability value is $0,000<0.05$, it is stated that the hypothesis is accepted because the p-value is 0.000 , which means that consumer behavior has a significant effect on the marketing mix.

2. H2 Hypothesis: The estimation of probability data at the incidence rate of $95 \%$ is obtained a probability value of $0.013<0.05$, it is stated that the hypothesis is accepted because the p-value is 0.013 , which means that social media advertising has a significant effect on the marketing mix.

3. Hypothesis H3: After a temporary guess test at the $95 \%$ certainty level obtained probability value of $0.875>0.05$, it is stated that the hypothesis is rejected because the probability is 0.875 , which means that consumer behavior has no effect on intellectual capital.

4. Hypothesis H4: From the allegations that have been made with $95 \%$ certainty obtained an opportunity value of $0,000<0.05$, stated that the hypothesis is accepted because the probability is 0,000 , which means social media advertising has a significant effect on intellectual capital.

5. Hypothesis H5: While testing the allegations at the $95 \%$ certainty level found an opportunity value of $0.367>0.05$, it was stated that the hypothesis was rejected because the p-value was 0.367 , which means intellectual capital did not affect the marketing mix.

\section{Direct, Indirect and Total Indications}

Live testing is a cause of consumer behaviour with a marketing mix, the influence of social media ads on the marketing mix and the influence of 
Intellectual capital towards the marketing mix. The test through is is followed by a connecting indicator that is the impact of consumer behaviour with the marketing mix through intellectual capital, as well as the impact of social media ads to the marketing mix through intellectual capital.

To know the intended influence and passing through the intermediaries of consumer behaviour (X1) and social media ads (X2) on the Marketing Mix (Y) as well as the reason for Intellectual Capital $(Z)$ such as the data presented below:

Table 12. Direct and Indirect Effects of X1, X2 on Y and their impact on $\mathrm{Z}$ and Total Influence

\begin{tabular}{|c|c|c|c|}
\hline Influence of Variables & $\begin{array}{c}\text { Direct } \\
\text { Influence }\end{array}$ & Indirect Influence & Total \\
\hline $\begin{array}{c}\text { Consumer behavior } \rightarrow \\
\text { Marketing Mix }\end{array}$ & 0.476 & 0 & 0.476 \\
\hline $\begin{array}{l}\text { Consumer behavior } \\
\rightarrow \text { Intellectual Capital }\end{array}$ & & $\begin{array}{l}\text { Marketing Mix } \\
-0.016+0.084\end{array}$ & 0.068 \\
\hline \multicolumn{3}{|c|}{$\begin{array}{c}\text { Effect of Total Consumer Behavior on } \\
\text { Marketing Mix }\end{array}$} & 0.544 \\
\hline $\begin{array}{c}\text { Social Media Advertising } \\
\rightarrow \\
\text { Marketing Mix }\end{array}$ & -0.282 & 0 & -0.282 \\
\hline $\begin{array}{l}\text { Social Media Advertising } \\
\rightarrow \text { Intellectual Capital }\end{array}$ & & $\begin{array}{c}\text { Marketing Mix } \\
0.606+0.084\end{array}$ & 0.690 \\
\hline \multicolumn{3}{|c|}{$\begin{array}{c}\text { The Total Effect of Social Media Ads on } \\
\text { Marketing Mix }\end{array}$} & 0.408 \\
\hline $\begin{array}{l}\text { Intellectual Capital } \rightarrow \\
\text { Marketing Mix }\end{array}$ & 0.084 & 0 & 0.084 \\
\hline \multicolumn{3}{|c|}{ amount } & 1,036 \\
\hline
\end{tabular}

From the results of the data processing has been tested to obtain direct implications of consumer behaviour with the marketing mix is 0476 (47.6\%) And the implications of the Interinter Intellectual Capital is 0068 (6.8\%). The direct indication of consumer behaviour towards the marketing mix is 0544 (54.4\%).

Direct implications of social media ads to a marketing mix of-0282 (28.2\%) and indirectly through Intelectual Capital worth of 0690 (69\%). The Total influence of social media ads to the marketing mix is $0408(40.8 \%)$.

\section{CONCLUSION}

The second variable of social media ads has a positive causal relationship to the suggestion mix. The social media ad indicator is a formative indicator that forms a 
constructed variable. The indicator of social media ads contains updated information to customers, the source is right in fulfilment, price determination, the convenience of access for public consumption. Therefore, the construct variables make a significant impact on the marketing mix.

Consumer behaviour in this research does not affect intellectual capital. The results of data processing acquired indirect influence of consumer behavior through intellectual capital is $0068(6.8 \%)$, while the indirect influence of social media advertising through intellectual capital is $0690(69 \%)$ and intellectual capital influences on the marketing mix of $8.4 \%$. From the results of the data test, the intervening influence is derived from the questionnaire data provided and there is still inconsistent answers that answer the question of more than 1 answer or unfamiliarity of respondents more in the sense of intellectual capital itself in the scientific language in this research.

Social media advertising is positively implicit and drastic to intellectual capital based on an indicator of the respondent's statement regarding the information on social media marketing information, the ease of access needed, the availability of a strategy or information training in the start up business and the ease of promotion of efficient products or services in terms of cost to the marketing mix.

Intellectual capital as a variable that connects another variable with a statistical test of opinion according to (Andriana, 2014) gives the intellectual property of a negative impact to the financial statements derived from the marketing mix. The negative influence of intellectual capital on marketing mix indicates that the use of media technology and information marketing techniques has not been implemented effectively and efficiently.

\section{RECOMMENDATION}

This study has limitations on the millennials alone so that subsequent research can explore more broadly from the more developed phenomena in the development of marketing strategies by other researchers. For further researchers can collaborate from the research gap between researchers in order to produce the latest grand theory. The inconsistency of the results of the research of respondents in this study can be a comparison for subsequent researchers.

The development of the latest marketing phenomenon that causes incompatibility with theory can be a source of problems and expansion of indicators in research material. The next researcher is to broaden the scope of discussion across generations. Besides, marketing mix measurement tools can be expanded using marketing intelligence strategies, concentration diversification, and competitor maneuvers in the effectiveness of marketing mix.

\section{REFERENCES}

[1] Z. Wang, N. Wang, and H. Liang, "Knowledge sharing, intellectual capital and firm performance," Manag. Decis., 2014, doi: 10.1108/MD-02-2013-0064.

http://ijstm.inarah.co.id 
[2] X. Wu and V. Sivalogathasan, "Intellectual Capital for Innovation Capability: A Conceptual Model for Innovation,” Int. J. Trade, Econ. Financ., 2013, doi: 10.7763/ijtef.2013.v4.274.

[3] S. Cabrilo and S. Dahms, "How strategic knowledge management drives intellectual capital to superior innovation and market performance," J. Knowl. Manag., 2018, doi: 10.1108/JKM-07-2017-0309.

[4] D. A. Klein, The strategic management of intellectual capital. 2009.

[5] A. Kalkan, Ö. Ç. Bozkurt, and M. Arman, "The Impacts of Intellectual Capital, Innovation and Organizational Strategy on Firm Performance," Procedia - Soc. Behav. Sci., 2014, doi: 10.1016/j.sbspro.2014.09.025.

[6] D. Palacios-Marqués, J. M. Merigó, and ..., "Online social networks as an enabler of innovation in organizations," Manag. ..., 2015.

[7] R. Wardrop, B. Zhang, R. Rau, and M. Gray, "Moving mainstream," Eur. Altern. ..., 2015.

[8] O. Lentjusenkova and I. Lapina, "Intellectual Capital Investments: Company's Additional Expenditures or Creating Shared Value,” Perspect. Bus. ..., 2015.

[9] I. Lapina, "Intellectual capital investments: Company's aditional expenditures or creating shared value?," Perspect. Bus. Entrep. Dev. Econ. Manag. Financ. Syst. Eng. from Acad. Pract. Views, 2015.

[10] J. Raco, J. Ohoitimur, and K. Sobon, "Spirituality: The Power of Entrepreneurship," EMAJ Emerg. Mark. J., vol. 9, no. 1, pp. 28-35, Aug. 2019, doi: 10.5195/emaj.2019.161.

[11] O. Ali and J. Soar, "Technology Innovation Adoption Theories," 2016, pp. 1-38.

[12] S. G. Lee, S. Trimi, W. K. Byun, and M. Kang, "Innovation and imitation effects in Metaverse service adoption," Serv. Bus., vol. 5, no. 2, pp. 155-172, 2011, doi: 10.1007/s11628-011-0108-8.

[13] G. Kannan and W. G. Aulbur, "Intellectual capital: Measurement effectiveness," Journal of Intellectual Capital. 2004, doi: 10.1108/14691930410550363.

[14] A. BROYAKA, "CONSUMER BEHAVIOUR IN THE MODERN MARKET ECONOMY," "ECONOMY. FINANCES. Manag. Top. issues Sci. Pract. Act., 2019, doi: 10.37128/2411-4413-2019-4-4.

[15] I. Bursuk, A. Mladenow, N. M. Novak, and C. Strauss, "Online cofounder search in tech startups," in ACM International Conference Proceeding Series, 2016, pp. 482-488, doi: 10.1145/3011141.3011221.

[16] C. Pelau, a. Vladoi, M. Fufezan, V. M. Dinca, and V. Ghinea, "The Influence of Knowledge Dynamics on Consumer Behaviour," Proceeding 2 nd Eur. Conf. Intellect. Cap., 2010.

[17] E. Scarmozzino, V. Corvello, and M. Grimaldi, "Entrepreneurial learning through online social networking in high-tech startups," Int. J. Entrep. Behav. Res., 2017, doi: 10.1108/IJEBR-12-2015-0302.

[18] J. Wee and A. Chua, "The Communication of Intellectual Capital-Prevalence and Relationship with Organizational Performance," Electron. J. Knowl. Manag., vol. 13, no. 1, pp. 38-50, 2015.

[19] A. Lazazzara, E. Della Torre, and R. C. D. Nacamulli, "Understanding the relationship between intellectual capital and organizational performance: The role of e-HRM and 
performance pay," in Lecture Notes in Information Systems and Organisation, 2020, vol. 33, pp. 151-164, doi: 10.1007/978-3-030-23665-6_11.

[20] M. Zeng, J. Jia, J. Tang, H. Li, T. Wang, and W. Zhou, “Application of CRM on power marketing," in IET Conference Publications, 2006, no. 527 CP, pp. 20-26, doi: 10.1049/cp:20061793.

[21] N.-M. Yaghoubi, H. Salarzehi, J. Moloudi, and E. Yaghoubi, "Review of Relationship between Intellectual Capital and Organizational Justice," Asian Soc. Sci., vol. 6, no. 10, 2010, doi: 10.5539/ass.v6n10p120.

[22] T. F. Chang and H. Su, The hidden cost of quality and the intellectual capital. 2002.

[23] M. J. Kwon, J. Han, B. H. Kim, Y. S. Lee, and ..., “... acid fragments mediated skin inflammation by inhibition of toll-like receptor 4 signaling pathway: superoxide dismutase 3 inhibits reactive oxygen species-induced ...," Antioxidants redox ..., 2012.

[24] F. Shahveisi, M. Heydari, and N. R. Nasab, "Impact of intellectual capital on cost of capital and market value,” Int. J. Sci. Manag. Dev., vol. 3, no. 1, pp. 811-818, 2015.

[25] D. Aruppala, V. Wickramasinghe, and I. Mahakalanda, "INTELLECTUAL CAPITAL AND FINANCIAL PERFORMANCE IN," Int. Conf. Bus. Inf., pp. 37-49, 2015.

[26] M. Joshi, D. Cahill, J. Sidhu, and M. Kansal, "Intellectual capital and financial performance: an evaluation of the Australian financial sector," J. Intellect. Cap., vol. 14, no. 2, pp. 264-285, 2013, doi: 10.1108/14691931311323887.

[27] M. Libyanita and Wahidawati, "The Effect of Intellectual Capital to Financial Performance on Banking Sector,” J. Ilmu Ris. Akunt., vol. 5, no. 6, pp. 1-19, 2016.

[28] R. Yang, W. Hu, L. Xu, Y. Song, and J. Li, "Synthesis, mechanical properties and fire behaviors of rigid polyurethane foam with a reactive flame retardant containing phosphazene and phosphate," Polym. Degrad. Stab., 2015.

[29] S. N. Hashemi and M. Azimiyancheshmeh, "Value-relevance of intellectual capital productivity," Int. J. Econ. Res., vol. 14, no. 4, pp. 377-386, 2017.

[30] C. Kohli and L. Leuthesser, "Brand Equity: Capitalizing on Intellectual Capital," Ivey Bus. J., vol. 65, no. 4, p. 74, 2001.

[31] P. Kurz, "Intellectual capital management and value maximization," Technol. Law Insur., vol. 5, no. 1-2, pp. 27-32, 2000, doi: 10.1080/13599370050028585.

[32] S. Pekkola et al., "Value creation through measurement of innovation capability - An intellectual capital management perspective," Int. J. Intell. Enterp., vol. 2, no. 2-3, pp. 196-212, 2014, doi: 10.1504/IJIE.2014.066675.

[33] N. S. Subawa, N. W. Widhiasthini, P. A. T. P. Pika, and P. I. Suryawati, "Hedonism on the behavior of consumer society as a global cultural transformation," Int. Res. J. Manag. IT Soc. Sci., vol. 7, no. 2, pp. 59-70, 2020, doi: 10.21744/irjmis.v7n2.878.

[34] L. Mandell and L. S. Klein, "Motivation and financial literacy," Financ. Serv. Rev., 2007.

[35] O. B. Buttner and A. S. Goritz, "Perceived trustworthiness of online shops," J. Consum. Behav., vol. 7, no. October, pp. 35-50, 2008, doi: 10.1002/cb.

[36] W. Shao, D. Grace, and M. Ross, "Consumer motivation and luxury consumption: Testing moderating effects," J. Retail. Consum. Serv., vol. 46, no. 2019, pp. 33-44, 2019, doi: 10.1016/j.jretconser.2018.10.003.

[37] Y. Truong and R. McColl, "Intrinsic motivations, self-esteem, and luxury goods consumption,” J. Retail. Consum. Serv., vol. 18, no. 6, pp. 555-561, 2011, doi: http://ijstm.inarah.co.id 
10.1016/j.jretconser.2011.08.004.

[38] M. A. Bernstein, "Consumer Behavior: Theory and Findings on Expectations and Aspirations," Am. Econ. Assoc., vol. 58, no. 2, pp. 19-30, 1968, doi: 10.1057/9780230226203.0037.

[39] J. N. Sheth, "The Surpluses and Shortages in Consumer Behavior Theory and Research," J. Acad. Mark. Sci., vol. 7, no. 4, pp. 414-426, 1979, doi: 10.1007/BF02729689.

[40] G. Wagner, H. Schramm-Klein, and S. Steinmann, "Online retailing across e-channels and e-channel touchpoints: Empirical studies of consumer behavior in the multichannel e-commerce environment," J. Bus. Res., vol. 107, no. May 2019, pp. 256-270, 2020, doi: $10.1016 /$ j.jbusres.2018.10.048.

[41] M. Maity, M. Dass, and P. Kumar, "The impact of media richness on consumer information search and choice," J. Bus. Res., vol. 87, no. January, pp. 36-45, 2018, doi: 10.1016/j.jbusres.2018.02.003.

[42] N. Zhong and D. A. Schweidel, "Capturing Changes in Social Media Content: A Multiple Latent Changepoint Topic Model," Mark. Sci., no. March, 2020, doi: 10.1287/mksc.2019.1212.

[43] B. L. Fossen and D. A. Schweidel, "Social TV, Advertising, and Sales: Are Social Shows Good for Advertisers?," Mark. Sci., vol. 38, no. 2, pp. 274-295, 2019, doi: 10.1287/mksc.2018.1139.

[44] H. Ting, W. W. P. Ming, E. C. de Run, and S. L. Y. Choo, "International Journal of Business and Innovation. Vol. 2, Issue 2, 2015," Int. J. Bus. Innov., vol. 2, no. 2, pp. 15-31, 2015.

[45] K. Lup, L. Trub, and L. Rosenthal, "Instagram \#Instasad?: Exploring Associations Among Instagram Use, Depressive Symptoms, Negative Social Comparison, and Strangers Followed," Cyberpsychology, Behav. Soc. Netw., vol. 18, no. 5, pp. 247-252, 2015, doi: 10.1089/cyber.2014.0560.

[46] B. B. Dedeoğlu, B. Taheri, F. Okumus, and M. Gannon, "Understanding the importance that consumers attach to social media sharing (ISMS): Scale development and validation," Tour. Manag., vol. 76, no. May 2019, 2020, doi: 10.1016/j.tourman.2019.103954.

[47] N. J. Evans, J. Phua, J. Lim, and H. Jun, "Disclosing Instagram Influencer Advertising: The Effects of Disclosure Language on Advertising Recognition, Attitudes, and Behavioral Intent," J. Interact. Advert., vol. 17, no. 2, pp. 138-149, 2017, doi: 10.1080/15252019.2017.1366885.

[48] J. C. Blankenship and R. Gibson, "Learning Alone, Together," Journal. Mass Commun. Educ., vol. 71, no. 4, pp. 425-439, 2015, doi: 10.1177/1077695815622113.

[49] G. Nicolo', F. Manes-Rossi, J. Christiaens, and N. Aversano, Accountability through intellectual capital disclosure in Italian Universities, no. Parker 2011. Springer US, 2020.

[50] T. Pucci, C. Simoni, and L. Zanni, "Measuring the relationship between marketing assets, intellectual capital and firm performance," J. Manag. Gov., vol. 19, no. 3, pp. 589-616, 2015, doi: 10.1007/s10997-013-9278-1.

[51] R. Almqvist and M. Skoog, "Colliding discourses? New Public Management from an Intellectual Capital perspective," Intellect. Cap. Revisit. - Parad. Knowl. Intensive 
Organ., no. March 2015, pp. 102-125, 2007.

[52] Choo and N. Bontis, The Strategic Management of Intellectual Capital and Organizational Knowledge. University Press, New York, 2002.

[53] J. Roos, G. Roos, N. C. Dragonetti, and L. Edvinsson, Intellectual Capital: Navigating in the New Business Landscape. NYU Press, 1998.

[54] T. A. Stewart, "Intellectual Capital: The New Wealth of Organizations. Doubleday, 1997.

[55] M. U. Rehman and N. Anjum, "Determination of the impact of working capital management on profitability: an empirical study from the cement sector in Pakistan," Asian Econ. Financ. Rev., 2013.

[56] E. Kong and S. B. Thomson, "An intellectual capital perspective of human resource strategies and practices," Knowl. Manag. Res. Pract., vol. 7, no. 4, pp. 356-364, 2009, doi: $10.1057 / \mathrm{kmrp} .2009 .27$.

[57] M. Acutt, "Marketing Mix Definition - 4Ps \& 7Ps of the Marketing Mix," Mark Acutt \& Patrick Kuo. 2015.

[58] W. Kenton and B. Abbott, "Marketing Mix Definition," Investopedia, 2019.

[59] Z. Yi, "The Marketing Mix and Branding," in Marketing Services and Resources in Information Organizations, 2018.

[60] B. F. Bowman and F. E. McCormick, "Market Segmentation and Marketing Mixes," J. Mark., 1961, doi: 10.2307/1249528.

[61] M. J. Baker, "The marketing mix," in The Marketing Book: Seventh Edition, 2016.

[62] M Išoraitè, "Marketing mix theoretical aspects," Int. J. Res. -Granthaalayah, 2016.

[63] S. V. Mamalyga and I. P. Sergin, "Theoretical aspects of relationship marketing," Actual Probl. Econ., no. 9, pp. 143-146, 2010.

[64] I. Margarita, "Theoretical Aspects of Marketing Strategy," Ekon. ir Vadyb. Aktual. ir Perspekt., vol. 1, no. 14, pp. 114-125, 2009.

[65] C. M. Fernández-Jardón and M. S. Martos, "Intellectual capital and competitive advantages in natural resource-based SMEs in Latin America," Innovar, 2016, doi: 10.15446/innovar.v26n60.55548.

[66] C. M. Jardon and N. Catalina, "Intellectual capital as a source of growth in subsistence small businesses in Latin America," Int. J. Entrep. Small Bus., 2015, doi: 10.1504/IJESB.2015.071322.

[67] C. M. Jardon and M. S. Martos, "Intellectual capital as competitive advantage in emerging clusters in Latin America," J. Intellect. Cap., 2012, doi: 10.1108/14691931211276098.

[68] S. Ahmed and H. Rahman, "The Effects Of Marketing Mix On Consumer Satisfaction," Turkish J. Islam. Econ., vol. 2, no. 1, p. 14, 2015, doi: http://dx.doi.org/10.15238/tujise.2015.2.1.17-30.

[69] S. Kamboj and Z. Rahman, "Marketing capabilities and firm performance: literature review and future research agenda," Int. J. Product. ..., 2015.

[70] S. Gilaninia, M. Taleghani, and N. Azizi, "Marketing Mix And Consumer Behavior," Kuwait Chapter Arab. J. Bus. Manag. Rev., vol. 2, no. 12, pp. 53-58, 2013, doi: 10.12816/0001270.

[71] D. M. Hanssens, K. H. Pauwels, S. Srinivasan, M. Vanhuele, and G. Yildirim, "Consumer attitude metrics for guiding marketing mix decisions," Mark. Sci., 2014, http://ijstm.inarah.co.id 
doi: $10.1287 / \mathrm{mksc} .2013 .0841$.

[72] N. Indumathi and A. K. Dawood, "Impact of marketing mix on consumer buying behavior in organic product," Int. J. Res. Financ. Mark., vol. 6, no. 10, pp. 43-54, 2016.

[73] M. Khalil Ur Rahman and M. Ayaz, "The Impact of Marketing Mix on Customer Buying Behavior: A Case Study of Footwear Industry," 2018.

[74] B. Nguyen, X. Yu, T. C. Melewar, and J. Chen, "Brand innovation and social media: Knowledge acquisition from social media, market orientation, and the moderating role of social media strategic capability," Ind. Mark. Manag., 2015, doi: 10.1016/j.indmarman.2015.04.017.

[75] M. Barari, M. Ross, and J. Surachartkumtonkun, "Negative and positive customer shopping experience in an online context," J. Retail. Consum. Serv., vol. 53, 2020, doi: 10.1016/j.jretconser.2019.101985.

[76] N. Piercy, "Marketing Intelligence \& Planning Positive and negative cross-channel shopping behaviour," Mark. Intell. Plan. Mark. Intell. \&amp; Plan. Iss J. Consum. Mark. Iss Int. J. Retail \&amp; Distrib. Manag., vol. 30, no. 3, pp. 9-24, 2012.

[77] N. Piercy, "Positive and negative cross-channel shopping behaviour," Mark. Intell. Plan., 2012, doi: 10.1108/02634501211193930.

[78] P. Sorce, V. Perotti, and S. Widrick, "Online Shopping for Positive and Negative Reinforcement Products," in The Social and Cognitive Impacts of e-Commerce on Modern Organizations, 2011, pp. 1-14.

[79] T. S. Edwin, A. Chandramohan, R. Shenbagavalli, and S. Senthilkumar, "Social media: The new hybrid factor of the promotion policy for the pharmaceutical industries," Int. J. Pharm. Sci. Rev. Res., vol. 32, no. 1, pp. 112-116, 2015.

[80] D. J. F. Mangold, W. Glynn, "Social media_the new hybrid element of the promotion mix," Bus. horizons. cited by 2000, vol. 12, no. 3, pp. 422-435, 2015, doi: 10.1016/j.jretai.2014.12.001.

[81] M. Yadav, Y. Joshi, and Z. Rahman, "Mobile Social Media: The New Hybrid Element of Digital Marketing Communications," Procedia - Soc. Behav. Sci., vol. 189, pp. 335343, 2015, doi: 10.1016/j.sbspro.2015.03.229.

[82] A. Bashar, I. Ahmad, and M. Wasiq, "Effectiveness of Social Media As a Marketing Tool: an Empirical Study,” Int. J. Mark. Financ. Serv. Manag. Res., 2012.

[83] S. Divya and B. Regi, "An empirical study on effectiveness of Social Media as a Marketing Tool," Int. J. Curr. Res. Acad. Rev., vol. 2, no. 3, pp. 2347-3215, 2014.

[84] K. Hutter, J. Hautz, S. Dennhardt, and J. Füller, "The impact of user interactions in social media on brand awareness and purchase intention: The case of MINI on Facebook," J. Prod. Brand Manag., 2013, doi: 10.1108/JPBM-05-2013-0299.

[85] Y. A. Kim and J. Srivastava, "Impact of social influence in e-commerce decision making," in ACM International Conference Proceeding Series, 2007, doi: 10.1145/1282100.1282157.

[86] W. Nabil Iblasi, D. M. Bader, and S. Ahmad Al-Qreini, "The Impact of Social Media as a Marketing Tool on Purchasing Decisions (Case Study on SAMSUNG for Electrical Home Appliances)," Int. J. Manag. Stud. Res., 2016.

[87] R. Fullerton, “the Impact of Social Media on Marketing Strategy," Dissertation, vol. 15, no. February, pp. 91-95, 2011.

http://ijstm.inarah.co.id 
[88] R. Kaushik, "the Impact of Social Media on Marketing Strategy," Dissertation, 2011.

[89] G. Ballot, F. Fakhfakh, and E. Taymaz, "Firms' human capital, R\&D and performance: A study on French and Swedish firms," Labour Econ., vol. 8, no. 4, pp. 443-462, 2001, doi: 10.1016/S0927-5371(01)00038-0.

[90] A. R. Belkaoui, "Intellectual capital and firm performance of US multinational firms," J. Intellect. Cap., vol. 4, no. 2, pp. 215-226, 2003.

[91] G. B. Kamath, "Impact of Intellectual Capital on Financial Performance and Market Valuation of Firms in India," Int. Lett. Soc. Humanist. Sci., vol. 48, pp. 107-122, 2015, doi: 10.18052/www.scipress.com/ilshs.48.107.

[92] A. Riahi-Belkaoui, "Intellectual Capital and Firm Performance of U.S. Multinational Firms: A Study of the Resource-Based and Stakeholder Views," SSRN Electron. J., 2005, doi: 10.2139/ssrn.365580.

[93] A. H. M. Ariff, A. Islam, and T. van Zijl, "Intellectual capital and market performance: The case of multinational R\&D firms in the U.S.," J. Dev. Areas, 2016, doi: 10.1353/jda.2016.0052.

[94] F. Calza, L. Dezi, F. Schiavone, and M. Simoni, "The intellectual capital of business incubators," J. Intellect. Cap., vol. 15, no. 4, pp. 597-610, 2014, doi: 10.1108/JIC-072014-0086.

[95] J. Davey, L. Schneider, and H. Davey, "Intellectual capital disclosure and the fashion industry," J. Intellect. Cap., 2009, doi: 10.1108/14691930910977815.

[96] Y. Ding, "Study on the Management of Intellectual Capital," Int. J. Bus. Manag., 2010, doi: 10.5539/ijbm.v5n2p213.

[97] G. S. Erickson and H. N. Rothberg, "Intellectual capital in business-to-business markets," Ind. Mark. Manag., 2009, doi: 10.1016/j.indmarman.2008.12.001.

[98] L. Indiran, Z. Khalifah, and K. Ismail, "A model for intellectual capital of business incubators," $A d v$. Sci. Lett., vol. 23, no. 9, pp. 8450-8457, 2017, doi: 10.1166/as1.2017.9909.

[99] S. Brahmi, S. Aitouche, and M. D. Mouss, "Measurement of Intellectual Capital in a Company,” Int. J. Econ. Manag. Eng., vol. 11, no. 5, pp. 843-849, 2017.

[100] L. FERNSTROM, "A Marketing Perspective on Intellectual Capital," in Perspectives on Intellectual Capital, 2005, pp. 82-95.

[101] N. Al Pop and C. Pelau, "The impact of relationship marketing on the development of the intellectual capital of a company," in Proceedings of the European Conference on Knowledge Management, ECKM, 2012.

[102] P. Kotler, N. Rackham, and S. Krishnaswamy, "Ending the war between sales and marketing," Harv. Bus. Rev., 2006.

[103] S. Mihic, D. Radjenovic, and D. Supic, "Consumer behaviour - building marketing strategy," Metal. Int., 2013.

[104] M. Pachauri, "Consumer Behaviour: a Literature Review," Mark. Rev., 2004, doi: $10.1362 / 1469347012569896$.

[105] L. G. Schiffman, L. L. Kanuk, and H. Hansen, Consumer Behaviour: A European Outlook. 2012.

[106] D. Aggarwal, "Mobile technology adoption by Indian consumers," Int. J. Recent Technol. Eng., vol. 8, no. 2 Special Issue 6, pp. 892-899, 2019, doi: 10.35940/ijrte.B1166.0782S619.

http://ijstm.inarah.co.id 
[107] C.-H. Chen and G. S. Mort, "Consumers' technology adoption behaviour: an alternative model," Mark. Rev., 2008, doi: 10.1362/146934707x251119.

[108] S. M. Golant, "A theoretical model to explain the smart technology adoption behaviors of elder consumers (Elderadopt)," J. Aging Stud., vol. 42, pp. 56-73, 2017, doi: 10.1016/j.jaging.2017.07.003.

[109] M. Bakator and D. Ivin, "Analysis of Consumer Behavior and Marketing Strategy Improvement," VI Int. Symp. Eng. Manag. Compet. , no. February 2019, pp. 201-205, 2016.

[110] D. L. Mothersbaugh and D. I. Hawkins, Consumer Behavior: Building Marketing Strategy, Thirteenth Edition. 2016.

[111] L. Perner, "Consumer Behavior: The Psychology Of Marketing," Marshall School of Business University of Southern California, 2010. [Online]. Available: http://www.consumerpsychologist.com/index.html.

[112] J. P. Peter and J. C. Olson, Consumer Behavior \& Marketing Strategy. 2009.

[113] J. P. Peter, Consumer behavior \&amp; marketing strategy. 2010. 